\title{
Facilitating Elements for the Transmission of the Entrepreneurial Spirit in the Classroom
}

\author{
José M. Comeche ${ }^{1} \&$ José V. Pascual $^{1}$ \\ ${ }^{1}$ Business Department, University of Valencia, Valencia, Spain \\ Correspondence: José M. Comeche, Business Department, University of Valencia, Avda. Tarongers s/n. Valencia, \\ Spain.Tel: 34-96-382-8888. E-mail: jose.m.comeche@uv.es
}

Received: February 25, 2014

Accepted: April 10, 2014

Online Published: April 21, 2014

doi:10.5430/bmr.v3n2p18

URL: http://dx.doi.org/10.5430/bmr.v3n2p18

\begin{abstract}
There have been countless tests made to confirm that creativity is a critical skill for entrepreneurs and their entrepreneurial training (Schmidt, J. et al. 2012), even more, practices on divergent thinking increases the entrepreneurial skills of students to generate a greater number and range of ideas, but not, their approaches to solve problems in a creative way. This situation raises a number of questions that should be analyzed before adding creativity and techniques to improve the training of creative thinking to studies (classes), about and in entrepreneurship, as a training channel, improvement or even to the generation of entrepreneurs.

Our goal is to show that entrepreneurship is a facet of creativity and that the "hidden" entrepreneur in the learner, will need to observe and confirm the existence of sufficient external constraints -context and social network- to release its entrepreneurial attitude, furthermore it will be essential, that teachers adopt an innovative approach that enables a suitable context, in this way almost intuitively, and vocational - show student behaviors associated with entrepreneurial attitudes.

In our work, we found out that the implementation of an innovative teaching contributes to facilitate the transmission of the entrepreneurial spirit and improves the use of gen-preneur in class.
\end{abstract}

Keywords: Education, Knowledge communication, Classroom, Entrepreneurship, Knowledge organization, Creativity

\section{Introduction}

The scientific and academic community (Bocconi, S. et al. 2012; Schmidt, J. et al. 2012; Van Treuren, K. et al., 2012) is showing a certain interest in analysing the appropriate strategies to explain the proper ways, to implement, develop and evaluate results of innovative, creative and entrepreneurial processes in the classroom. There have been countless tests made to confirm that creativity is a critical skill for entrepreneurs and entrepreneurial training. As some results show up (Schmidt, J. et al. 2012), students enrolled in the entrepreneurship class, at the end of training, have perceived themselves as more creative and with a better and divergent thinking; furthermore, it even seems that the practice of divergent thinking increases entrepreneurial skills of students to generate a greater number and range of ideas, but not, their approaches to solve creative problems.

This situation raises a number of questions, first of all, will some students participate in these practices to prevent or reduce the tedium of traditional classes, thereby seeking an alternative that will encourage them and obtain a substantial improvement of their personal satisfaction, freeing the mind and contributing thereby to the generation of larger and better ideas?

Secondly, would it be possible to think that having joined voluntarily to group analysis (entrepreneurial class), students who have done so are more likely than others to such practices due to the fact that they are different, alternative, creative and even amusing, and to which some people tend, because of their nature?

Third, is it possible to think that we are associating directly creativity with entrepreneurship when entrepreneurship can be defined as an integrated aspect of creativity, having every entrepreneur aspects associated or related to creativity, but not reversely? 
And fourthly, one more question, does everybody want to improve their creative skills? Do all people want to be entrepreneurs? How should the transmission process of entrepreneurship spirit in class be planned, transversely, or only to those who -voluntarily- wish it?

Why do we face these questions? Because the traditional point of view (Winslow \& Salomon, 1987, 1993; Fernald, 1988; Whiting, 1988) has attempted to relate creativity and entrepreneurship, if we consider the first as a characteristic of the second. The basis of our work presents entrepreneurship as an example of creativity, which is, as a particular case of creativity applied to the identification of opportunities, to the creation of businesses or other type of organizations, to pursue these opportunities, and to the development, in many occasions, of such organizations. And, we have the belief that you can teach entrepreneurship, you can teach/help to be more creative, but you cannot teach to be an entrepreneur, because is there a gene that predisposes a person toward entrepreneurial behaviour? Is it possible that some genes may make some people more sensitive than others to environmental stimuli? Is one born an entrepreneur? ... We believe that there may be a clear connection between the predisposition and entrepreneurial behaviour, -hereinafter called "entrepreneurship identity (Note 1)"- and certain genetic conditions, which we can also consider as vocational.

And that would be an answer to why, those who are released as volunteers to participate in Creativity vs. Entrepreneurship trials, shown at the end, attitudes and skills a bit more developed than participants in the control group. They are genetically more predisposed than others, which is the reason why they are willing to participate (Nicolaou, N. \& Shane, S., 2009).

But let us clarify some aspects instead of anticipating some conclusions:

Therefore in first place, we will enter the territory of creativity, trying to find the key that better contributes to transmit and generate entrepreneurial behaviour in the classroom.

Secondly, we discuss the development of the creative process in the classroom, on the assumption that we can and should manage environments that facilitate creativity as a necessary step for the development of a trained mind to pursue opportunities and solve problems.

And third, try to show that there is a genetic conditioning that predisposes some people to adopt behaviours that, could be linked to entrepreneurial behaviour and, that this conditioning disposes the potential entrepreneur to search, sometimes unaware of it, classmates and suitable partners or companions to his "entrepreneurship venturing" and even his instinctive location in fertile areas (industries).

Our goal, after studying the above mentioned aims, will be to demonstrate that the learner needs to observe and confirm the existence of sufficient external factors -context and social network- to release their entrepreneurial attitude and, so, almost intuitively, -vocational- adopting behaviours associated with entrepreneurial attitudes, which we must take into account when we design elements and activities intended to convey the entrepreneurship spirit in the classroom.

\section{A response to the definition of entrepreneurship: creativity. A model of creativity}

Given the need for companies to generate an ever increasingly higher performance, it has been ensured that innovation and creativity, in most organizations, are seen as a universal solution (Corrales, 1991). However, there is a certain consensus on the THREE elements generally recognized in creativity: regularity, novelty and acceptance or recognition (Gardner, 1993; Ludwig, 1995; Simonton, 1999). In a closer look, entrepreneurship can be considered as a special case of creativity. Indeed, the central role of the entrepreneur is the constant -regular- desire to "create" something after the detection and recognition of new opportunities (Kao, 1989). To understand more precisely how entrepreneurship is a particular facet of creativity, and its relationships, we will expose (Comeche, 2004) a model of creativity (Figure 1) developed from the detailed study of the recently reported in the literature on the subject (Baronet \& Pitcher, 1995). 


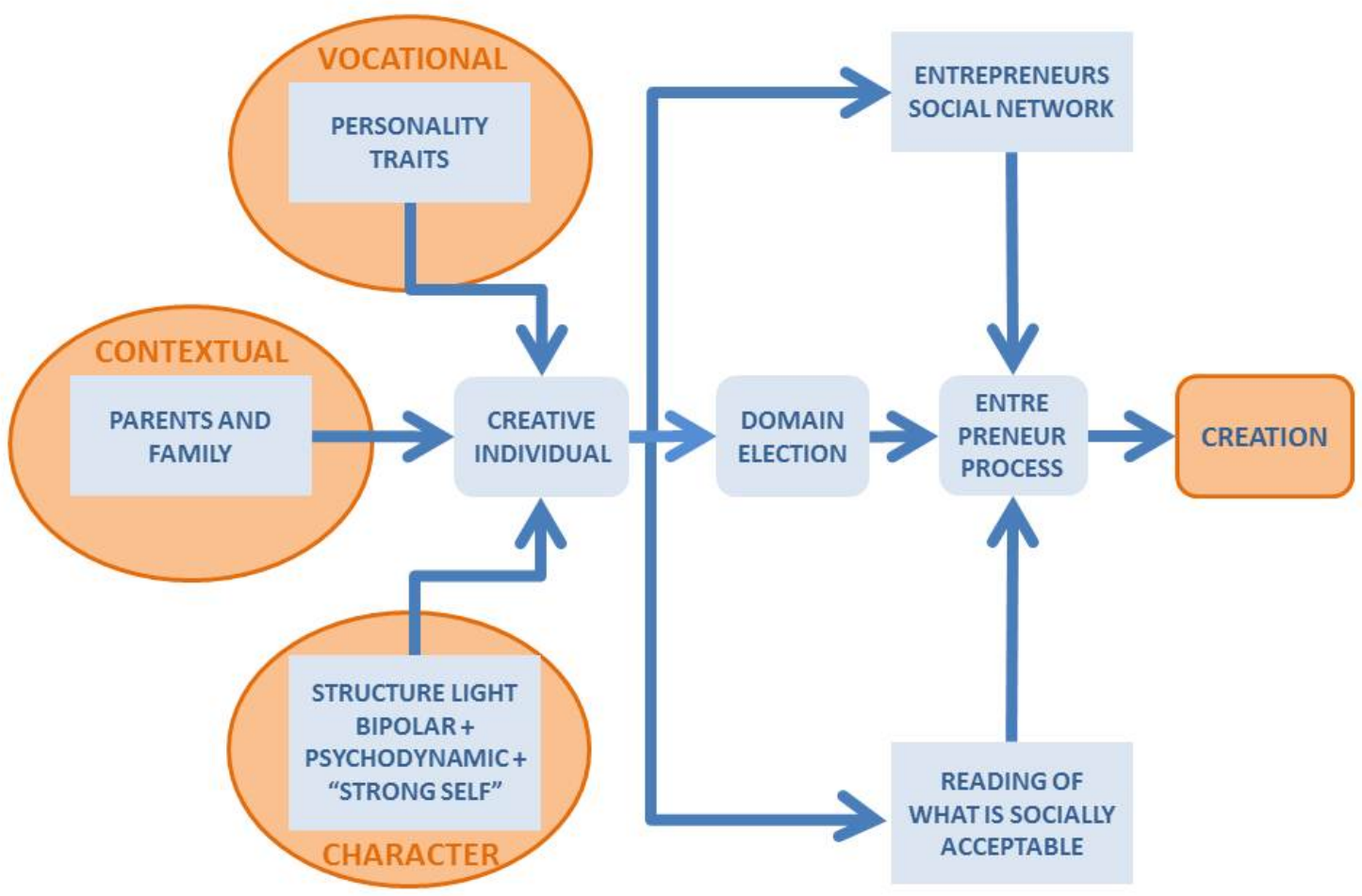

Source: Adapted from Baronet \& Pitcher (1995).

Figure 1. General model of creativity

\subsection{Creative process. Description and model}

Researches on this aspect have come to define FIVE major stages or phases in the so called creative process ranging from a kind of "intimation" during which the creator is literally repossessed or overwhelmed (Anzieu, 1981), to a phase of public exhibition in which the creator needs the social recognition of his creation and, that ultimately justifies the creation act (Land, 1975). In the business world and in the entrepreneurship in particular, these phases would refer to the performance in the market of a new idea or a new process or product (Land, 1975).

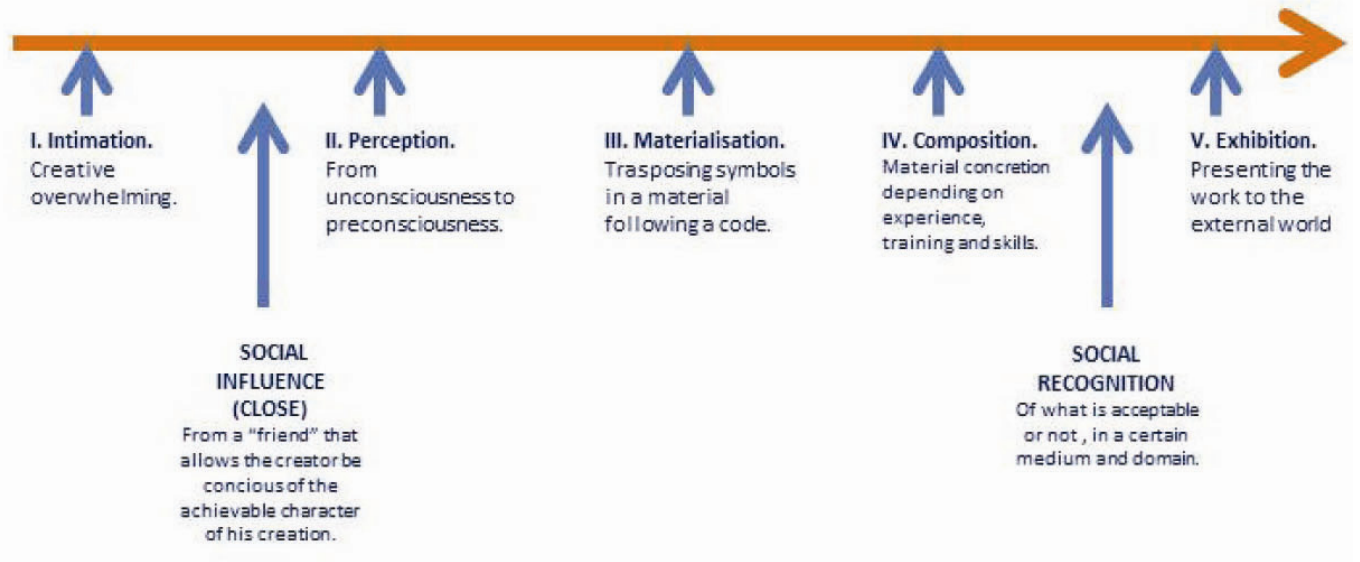

Source: Self Elaboration propia.

Figure 2. Model of the creative process. Stages 
In our model (Figure 2) we present what could be seen as a rough description of what happens in the brain and heart of the individual creator. During the first stage "the individual creator" is literally seized "as in a "psychotic episode —but not pathological—temporal" (Anzieu, 1974). We are talking about a confusing excitement, of a wish and of a kind of "intimation" to pursue any fundamental thing (Eysenck, 1994). Psychoanalysts refer to it as a "regression to serve the self" (Suler, 1980; Anzieu, 1981), which generates great disturbances. Therefore a "strong self" is needed in the character of the creator (Simonton, 1999). The second stage of the creating process is a stage of perception, where the creator passes from an unconscious to a preconscious state, usually due to third persons that help in the appreciation of the viability of the project. In the third stage, the creator materializes his creation, according to the codes of his activity scope; this is, according to his experience. The fourth stage corresponds to the, so named, composition. Where the individual uses his knowledge of the activity, he is working in, his experience, his formal and informal training and his skills to concrete his feelings and decodes. In this stage and in the next one, raise the recognition of what is acceptable, in a given environment and in a determinate domain. Therefore, it represents for the creator the beginning of the commitment between what he really wishes to express and what he shall do "to make it happen". The fifth and last stage is the exhibition of the work to the eternal world. Some creators have not passed the fourth stage and have not assumed the necessary commitment between their emotions and conflicts, and what is acceptable in the environment, maintaining creations that have not been made public and therefore remain as a dream. In business world and in entrepreneurship in particular, for example, this stage refers to the starting up in the market of a new idea or product (Land, 1975).

Creators build a mental plane, defined as a greater role in creativity "personal organization" of knowledge that represents, probably, the most important cognitive element. It is even more important than the amount of knowledge itself. In fact, it is this "organization" of knowledge what would enable the necessary knowledge associated with divergent originality and innovation.

We perceive here a key to the transmission techniques of entrepreneurship spirit in the classroom, at least tangentially to what will be discussed in depth later: you cannot teach entrepreneurship, we must teach to "organize" knowledge to promote a wider range of thinking or divergent knowledge, which will help the students group, to be more original, for example, to identify new opportunities, new deficiencies or needs or wishes to do new things -creations/ entrepreneurshipand bring them closer to commercial flow, namely, innovate.

\subsection{Belonging to a social network. Entailment}

Notwithstanding the foregoing, the individual creator is part of a field, a network of people and institutions who judge their work, that help (co-creation) and that sometimes even come into competition. The network, therefore, supports the creator to "lead" properly the creation to make it a successful creative act (Gardner, 1993). The studies of Moore (1986) and Bygrave (1989) show the influence of family, friends, mentors, investors, entrepreneurs and bankers -stakeholders- networks, combining the psychological characteristics of the entrepreneur and the level of the active environment in putting in scene the "new business" (Bygrave \& Hofer, 1991). The network also helps, the individual creator, to leave the natural insulation (Ripoll \& Menguzzato, 2004) building, together with the various agents of their economic and social environment an important source of resources to carry out the creation or company (Iborra, et al., 1998, Ripoll et al., 2002).

Arises hear, again, a new key that will help us answer the initial questions regarding the best method for transmitting the entrepreneurial spirit in the classroom. It is about the need to train the individual -student- in the development of social skills that allow the efficient interaction with the social network that defines its cognitive environment, for which it must incorporate techniques that help in the effective communication of their emotions and intentions, their affective approach and what, from a still unknown knowledge flows from their inside.

\section{Generation of propitious environments in the classroom: methodology and non-formal didactics. The use of media resources}

To nurture in class creative skills and stimulate the development of social skills that allow the potential entrepreneur, interact effectively with the social network that surrounds him we must first identify and define operationally the constitutive skills of creative talent, such as: fluency, flexibility and originality (Durán, C., 2006).

However, creative talent includes other features that are not structural. Additional factors referred to are: the tendency to redefine, processing, sensitivity to problems and evaluation (Herran, A., 2008). Understood as the ability to make more flexible the approach to the problem, reformulating if necessary, the ability to produce solutions or rational proposals; the agile perception of non-explicit or visible for the majority inconsistencies and the ability to judge the importance, quality and consistency of each element. In fact, genuine entrepreneurs stand out also for a 
powerful motivation for work, that is, by perseverance in creative projects, to assume them as essential aspects of life projects. So much so that, given the difficulties they seem to find stimuli rather than perish or give up, which again makes us think of some sort of motivational or genetic conviction that drives them towards, no matter what may happen, the initiated work, because it is their internal life motive.

It is important to consider this observation in the didactic field of creativity, that is to say, the context of the creator is determinant in the creative factor applied in the classroom. In this regard, anthropologists and historians have identified some factors of the physical environment related to cultural boom. Geographical factors such as climate create favourable conditions for inventiveness, because having free time enables the cultivation of creativity (Correa, P., 2011).

Let us analyse some of the fundamental conditions, conceived as a way of contextual improvement in class that influences the creative environment, as some authors point out, for the development of creativity in education:

a) First, we should note that most authors agree that the promotion of creativity requires a clear willingness on the part of the teacher (Torrance \& Myers, 1976), which is equivalent to saying that initially, not all teachers possess the skills and attitudes necessary to provide valid paradigms in this field.

b) The teacher must not repress the original responses and prosecute restrictively, even if it is argued, on its viability (Fernandez Huerta, 1968).

c) Educational creativity incorporates uncertainty among the goals to be achieved, meaning "awareness of two or more possible choices, each of which may, though not absolutely, lead to the right solution" (Seiber, 1978).

d) Encouraging creativity equals to promote contrast situations and among these, to highlight the role of irony and humour (Marin, 1980).

e) Sometimes creative partnerships arise from the space-time proximity -clash of cultures. (Marin, 1980).

f) The creative teacher uses anticipation in responses and simulation as exercises for inventive promoters (Sandi, 1980).

g) Finally, we cannot forget that, applied to the scientific field creativity equals to research.

If we now remember that creativity is essentially a type of synthetic learning, the first didactic principle that appears as necessary is the need to diversify sources of information and training (Sarramona, J., 1984). Indeed, if the uniqueness of the written source is removed and informational texts are diversified, inescapably, personal synthesis will be necessary to harmonize and structure the acquired knowledge.

On this basis, we can propose a second set of didactic principles that can be applied in the classroom (Maddison, 1971):

- The use of audio-visual resources will be valuable to encourage verbal creativity, specified in expressive fluency and the invention of new words.

- The dramatic programs (non-visual dramatization) are particular cases of stimulation and realization of original creations, where each listener generates a different temporal space as he recreates what he heard (Murga, 1983).

And finally, we cannot fail to note the evidence that teaching with computers represents in the field of non-formal methodology its fullest sense. Indeed, closely linked to problem solving, is the contribution of the computer in creating simulations that, as we have seen, is a valid technique to arouse creative thinking.

The road, then, seems clear: the media have to penetrate even further, in adult education programs and be used there for the benefit of optimizing goals, among which creativity cannot fail. Allowing the generation, encouragement and development of student skills that allow the efficient interaction with the social network and that defines its cognitive environment, incorporating techniques to effectively communicate their emotions and creative and entrepreneurial intentions.

\section{Genetic perspective and entrepreneurship: one more factor to be considered.}

We have the belief that you can teach to entrepreneur, you can teach/help to be more creative, but you cannot teach to be an entrepreneur, because specific techniques and practices can be taught, but the famous "will to conquer" cannot be taught (Falck, O. et al., 2012). Indeed, this essential attribute of the entrepreneur is part of the identity of the person who slowly develops, depending on the background and experience. At this point, we could ask, can one be born an entrepreneur? Is it possible that some genes may make some people more sensitive than others to 
environmental stimuli? Is there a gene that predisposes a person toward entrepreneurial behaviour? We believe that there may be a clear connection between the predisposition and entrepreneurial behaviour and certain genetic conditions, which we could also name, vocational.

For 40 years, researchers have examined who and why becomes entrepreneur (Gartner, 1988; Bird, 1989; Shane \& Venkataraman, 2000; Aldrich \& Martinez, 2001; Baron, 2004). However, one of the most interesting explanations of the tendency of people to start an entrepreneurial activity has not been extensively examined (genetic perspective or "vocational"). Several studies (Nicolaou, N. \& Shane, S., 2009) warn that genetic factors may influence the tendency of people to engage in entrepreneurial activity.

Nevertheless, we agree beforehand that specific genes do not cause in people starting or participating in social activities such as entrepreneurship, however, we do understand that genes and environment can work together and influence the tendency of people to join or start an entrepreneurial activity through a mechanism called Geno-Environment interaction. Such is the effect of this mechanism in childhood that it is more accepted than corporate identity (Falck, O. et al., 2012) -inclination to certain behaviours with desired business oriented intentions-, together with certain skills, results from a socialization of individuals at home and at school (Akerlof \& Kranton, 2005). It seems plausible to assume, therefore, that a tilted identity to develop entrepreneurship is similar, namely, to building environments (school and family) that encourage the development of cognitive entrepreneurial abilities. On the other hand, we know that genes address people to select, modify and build their environment (Scarr, 1992), and that environmental factors are not randomly distributed among people of different genetic compositions (Neale \& Maes, 2002). Thus, genes may also influence the tendency of some people to initiate or participate in entrepreneurial activities through the selection of other people (partners) in different environments.

In fact, genetic factors influence the skills that people have. These skills enable people to choose a job in different industries, since different industries have different opportunities to initiate or participate in an entrepreneurial activity, geno-environment interactions influence the tendency of some people to initiate or participate in an entrepreneurial activity.

Education also provides with the necessary knowledge background to identify new business opportunities (Shane, 2000) and the analytical skills to evaluate them (Clouse, 1990). A large number of studies have provided consistent evidence of the positive relationship between education and entrepreneurial activity in the U.S. and in Sweden, the UK and Finland (Borjas, 1986; Rees \& Shah, 1986; Macpherson, 1988; Borjas \& Bronars, 1989, Boyd, 1990, Fernandez \& Kim, 1998; Delmar \& Davidsson, 2000; Ritsila \& Tervo, 2002; Davidsson \& Honig, 2003). Finding empirical evidence that education is affected by genetic factors, it seems logical that genetic factors influence the level of education people achieve. Since, therefore, that people with higher education levels are more likely than others to initiate or participate in entrepreneurial activities, might think that the geno-environment interactions influence not only the tendency of some people to initiate or participate in entrepreneurial activities even more, influence the selection-, sometimes intuitively, travelling companions (college, school, neighbourhood, club, company, office, etc.) because some studies (Falck, O. et al., 2012) have found sufficient empirical support for the hypothesis that "having fellow entrepreneurs in school -school years- has a high impact on the development of future entrepreneurs/entrepreneurial intentions of the individual in that age group (about 15 years). Furthermore, there is sufficient evidence that entrepreneurial intentions in adolescence are a clear and a good predictor of the possibility of becoming a future entrepreneur".

The foregoing seduces in a way that encourages us to consider the geno-environment as a decisive factor in identifying and even generate appropriate environments for our students, future entrepreneurs, so that they can find the necessary and sufficient conditions to explode all their inner potential.

\section{Conclusions and future research lines.}

After our review, we can see that, actually, there are a certain number of clues that could facilitate the transmission of the entrepreneurship spirit in the classroom;

1) In first place, the change in the behaviour of teachers, addressed to the creation of favourable and propitious environments that will allow us to generate what we call "entrepreneurial groups" on which it will be easy to implement other keys for generating and transmitting, and why not, develop the entrepreneurship spirit in the classroom.

2) In second place, a change in the teachers attitude, related to for their tendency to teach entrepreneurship as virtually the only entrepreneurial way. Insisting, we should not pretend to provide more and more 
knowledge about entrepreneurship, we should teach to "organize" knowledge as a tool to foster in students the routine of divergent thinking oriented to the detection of opportunities and innovation.

3) The third key would be the relative need to develop social skills that enable them to interact efficiently with the social network, including, for this purpose, effective communication techniques enabling the transmission of emotions, intentions and projects, and everything that flows from the inside of the entrepreneur.

As we see, what we have concluded until now needs the change and/or correct teacher's behaviour in the classroom, guiding directly and clearly his attitude towards enhancing the entrepreneurial side of the student. However, we shall not forget the need to use besides, without forgetting them, traditional training techniques; other non-formal techniques that, in our work, have been shown to enhance the creative talent, which is what we named didactic principles:

1. Need to diversify training and information sources.

2. Using audio visual resources.

3. Application of non-visual dramatization.

4. Creating simulations.

These principles, applied in the classroom, enhance, stimulate and develop in students a range of skills that allow them to interact more efficiently with the social network that defines its cognitive environment, communicating more efficiently their entrepreneurial intentions, emotions and intuitions as we can see bellow (Figure 3).

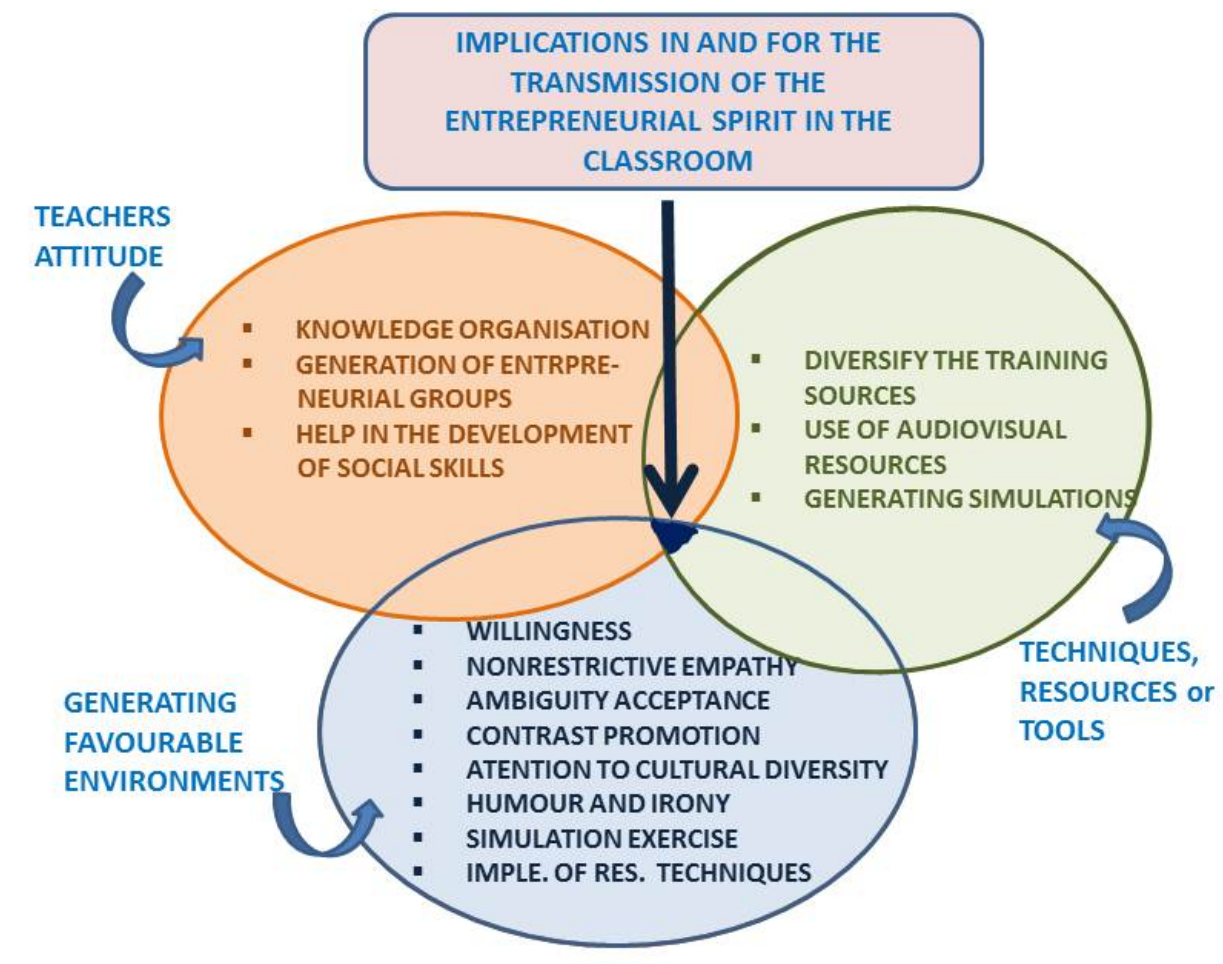

Source: Self Elaboration.

Figure 3. Model and facilitators for the transmission of the entrepreneurial spirit in the classroom

Finally, another aspect to be considered, is the students vocational perspective, the experiential environments for children and youth, family, companions, etc..., that are crucial for the promotion of the entrepreneurial spirit, and it is therefore vital for building environments (family, friends, school...) that support the development of cognitive entrepreneurial abilities of the student. 


\section{Limitations}

We are aware of the limitations of the present work and of the need to introduce an empirical study of what we propose. Our purpose is to introduce it in and for a future work; in fact, we have introduced in the classroom in several stages-courses-, the suggested changes. Our intention is to collect, shortly the obtained results and show -if the results confirm it- that the implementation of innovating didactic elements better the transmission process of the entrepreneur spirit in class, obtaining students with a higher level of entrepreneurial perception.

\section{References}

Akerlof, G.A. \& Kranton, R.E. (2005). "Identity and the economics of organizations". Journal of Economic Perspectives. Vol.19, pp. 9-32. http://dx.doi.org/10.1257/0895330053147930

Aldrich, H.E. \& Martínez, M.A. (2001). "Many are called but few are chosen: An evolutionary perspective for the study of entrepreneurship". Entrepreneurship Theory \& Practice. Núm. 25 (summer), pp. 41-56.

Anzieu, D. (1974), Psychanalyse de génie créateur. Paris: Dunod.

Anzieu, D. (1981). Le corps de l'oeuvre. Paris: Gallimard.

Baron, R.A. (2004).“The cognitive perspective: A valuable tool for answering entrepreneurship's basic "why" questions". Journal of Business Venturing. Vol. 19, núm. 2, pp. 221-239. http://dx.doi.org/10.1016/S0883-9026(03)00008-9

Baronet, J. \& Pitcher, P. (1995). Créativité, leadership, stratégique et entrepreneurship: trois facettes d'une meme réalité. Montreal, Québec: Chaire d'entrepreneurship Maclean Hunter. École des Hautes Études Commerciales-HEC.

Bird, B. (1989). Entrepreneurial Behavior. Glenview, IL.: Scott, Foresman \& Co.

Bocconi, S., Kampylis, P.G. \& Punie, Y. (2012)."Innovating Learning: Key Elements for Developing Creative Classrooms in Europe". Joint Research Centre - Institute for Prospective Technological Studies. European Commission. Publications Office of the European Union: Luxembourg.

Borjas, G. (1986). "The Self-Employment Experience of Immigrants”. Journal of Human Resources. Vol. 21, pp. 485-506. http://dx.doi.org/10.2307/145764

Borjas, G.J. \& Bronars, S.G. (1989). "Consumer Discrimination and Self-employment". Journal of Political Economy. Vol. 97, pp. 581-605.

Bouchard, T.J. Jr.; Lykken, D.T.; McGue, M. \& Tellegen, A. (1997). Genes, drives, environment and experience: EPD theory revised. In C. Benbow and D. Lubinski (Eds.). Intellectual Talent: Psychometric and Social Issues. Johns Hopkins University Press, t-43: Baltimore.

Boyd, R.L. (1990). "Black and Asian self-employment in large metropolitan areas: a comparative analysis". Social Problems. Vol. 37, pp. 258-272. http://dx.doi.org/10.2307/800652

Bygrave, W.D. \& Hofer, C.W. (1991). "Theorizing about entrepreneurship". Entrepreneurship Theory and Practice. Vol. 16, núm. 1, pp. 7-30.

Bygrave, W.D. (1989). "The entrepreneurship paradigm (I): A philosophical look at its research methodologies". Entrepreneurship, Theory and Practice. Vol. 14, núm. 2, pp. 7-26.

Clouse, V. (1990)."A controlled experiment relating entrepreneurial education to students' start-up decisions". Journal of Small Business Management. Vol. 28, pp. 45-53.

Comeche, J.M. (2004). "Factores explicativos de la existencia de emprendedurismo colectivo en las pyme: aplicación a las empresas de la Comunidad Valenciana". Tesis Doctoral. Universitat de València.

Corrales, J. (1991). La gestión creativa. Madrid: Paraninfo.

Correa, P. (2011). Procesos creativos. Polémikus. Ciencias de la Comunicación - Los Libertadores. Universidad Jorge Tadeo Lozano. Colombia. Pp. 11-21.

Davidsson, P. \&Honig, B. (2003).“The role of social and human capital among nascent entrepreneurs”. Journal of Business Venturing. Vol. 18, núm. 3, pp. 301-331. http://dx.doi.org/10.1016/S0883-9026(02)00097-6

Delmar, F. \& Davidsson, P. (2000). "Where do they come from? Prevalence and characteristics of nascent entrepreneurs". Entrepreneurship and Regional Development. Vol. 12, pp. 1-23. http://dx.doi.org/10.1080/089856200283063 
Durán, C. (2006). "La creatividad como actitud". Revista Ctrl $+G$, Escuela de Diseño Gráfico de la Universidad del Pacífico. Santiago de Chile.

Eysenck, H.J. (1994), "Creativity and personality: Word association, origence, and psychoticism", Creativity Research Journal, Vol. 16, núm. 2, pp. 206-209.

Falck, O., Heblich, S. \& Luedemann, E. (2012). "Identity and entrepreneurship: do school peers shape entrepreneurial intentions?" Small Business Economics. Vol. 39, pp. 39-59. http://dx.doi.org/10.1007/s11187-010-9292-5

Fernald, J.W. Jr. (1988). "The underlying relationship between creativity, innovation and entrepreneurship". Journal of Creative Behaviour. Vol. 22, núm. 2, pp. 196-202. http://dx.doi.org/10.1002/j. 2162-6057.1988.tb00497.x

Fernández Huerta, J. (1968). “¿Cómo desarrollar la originalidad y la inventiva del alumno durante la escolaridad?”. Madrid: Tiempo y Educación. Ed. Compi.

Fernández, M. \& Kim, K. (1998). "Self-Employment Rates of Asian Immigrant Groups: An Analysis of Intre-Group and Inter-Group Differences". International Migration Review. Vol. 32, pp. 654-681. http://dx.doi.org/10.2307/2547767

Gardner, H. (1993). Creating minds. New York: Basic Books.

Gartner, W. (1988). "Who is an entrepreneur? Is the wrong question". American Journal of Small Business. Vol. 12, núm. 4, pp. 11-32.

Herrán, A. de la (2008). Didáctica de la creatividad. Madrid: Universidad Autónoma de Madrid.

Iborra, M.; Menguzzato, M. \& Ripollés, M. (1998). "Creación de empresas internacionales: Redes informales y obtención de recursos". Revista Europea de Dirección y Economía de la Empresa. Vol. 7, núm. 3, pp. 147-160.

Kao, J. (1989). Entrepreneurship, Creativity and Organization. Text, cases and readings. Englewood Cliffs. NJ: Prentice Hall.

Land, E. (1975). "People should want mare from life". Forbes. June 1, pp. 48-50.

Ludwing, A.M. (1995). The price of greatness. New York: Guilford Press.

Macpherson, D. (1988). "Self-employment and married women". Economic Letters. Vol. 28, pp. 281-284. http://dx.doi.org/10.1016/0165-1765(88)90132-2

Maddison, J. (1971). Le rôle de la radio et de la télévision dans l'alphabetisation. Unesco. Paris.

Marín, R. (1980). La creatividad. Barcelona: Ceac Editorial.

McGue, M.; Bouchard, T.; Iancono, W. \& Lykken, D. (1993). "Behavioural genetics of cognitive ability: A life-span perspective" in R. Plomin and G. McGlearn (eds.). Nature, Nurture and Psychology. Pp. 59-76. Washington D.C.: American Psychological Association. http://dx.doi.org/10.1037/10131-003

Moore, C.F. (1986). "Understanding entrepreneurial Behaviour", in Pearce II, J.A. \& Robinson, R.B. (eds.). Academy of Management Best Papers Proceedings, pp. 66-70. Forty-sixth Annual Meeting of the Academy of Management. Chicago: Academy of Management.

Murga, M.A. (1983). La radio educativa en la UNED: utilidad y eficacia. Madrid: UNED.

Neale, M.C. \& Maes, H.H.M. (2002). Methodology for genetic studies of twins and families. Dordrecht, Netherlands: Kluwer Academic Publishers.

Nicolaou, N. \& Shane, S. (2009). "Born Entrepreneurs? The Genetic Foundations of Entrepreneurship". Journal of Business Venturing. Vol. 23, pp. 1-22. http://dx.doi.org/10.1016/j.jbusvent.2007.11.003

Rees, H. \& Shah, A. (1986). "An Empirical Analysis of Self-Emplyment in the OK". Journal of Applied Econometrics. Vol. 1, pp. 95-108. http://dx.doi.org/10.1002/jae.3950010107

Ripollés, M. \& Menguzzato, M. (2004). "International entrepreneurship: ¿Nuevas empresas internacionales y/o empresas nacidas globales?", en Roig, S. et al. (eds.). El emprendedor innovador y la creación de empresas de $I+D+i$, pp. 59-69. Valencia: Universitat de València.

Ripollés, M.; Menguzzato, M. \& Iborra, M. (2002). "The internationalisation of new ventures. The Spanish case". International Journal of Entrepreneurship and Innovation 2002. Vol. 3, núm. 3, pp. 191-200. 
Ritsila, J. \& Tervo, H. (2002). "Effects of Unemployment on New Firm Formation: Micro-level Panel Data Evidence from Finland”. Small Business Economics. Vol. 19, pp. 31-40. http://dx.doi.org/10.1023/A:1015734424259

Sandi, A.M. (1980). "Información de masas y educación”. Perspectives I. Vol. X. París.

Sarramona, J. (1984). "Educación de adultos por metodología no-formal". Modelos formales y no formales. I Jornadas de Educación de Adultos. Universidad Popular de Zaragoza. Pp. 33-41.

Scarr, S. (1992). "Developmental theories for 1990s: Development and individual differences". Child Development. Vol.63, pp. 1-19. http://dx.doi.org/10.2307/1130897

Schmidt, J, Soper, J. \& Bernaciak, J. (2013). "Creativity in the Entrepreneurship Program: A Survey of the Directors of Award Winning Programs". Journal of the Entrepreneurship Education, Vol. 16, pp. 31-44.

Schmidt, J., Soper, J. \& Facca, T. (2012). "Creativity in the entrepreneurship classroom". Journal of Entrepreneurship Education. Vol. 15, pp. 123-131.

Seiber, J.E. (1978). "Lecciones de incertidumbre”, en Guilfort, P. et al. Creatividad e Innovación. Buenos Aires: Ed. Paidos.

Shane, S, Venkataraman, S. (2000)."The promise of entrepreneurship as a field of research". Academy of Management Review. Núm. 25, pp. 217-226.

Shane, S. (2000). "Prior knowledge and the discovery of entrepreneurial opportunities". Organization Science. Vol. 11, pp. 448-469. http://dx.doi.org/10.1287/orsc.11.4.448.14602

Simonton, D.K. (1999). Origins of genius. Darwinian perspectives on creativity. New York: Oxford University Press.

Suler, J.R. (1980), "Primary process thinking and creativity", Psychological Bulletin, Vol. 88, núm. 1, pp. 144-165. http://dx.doi.org/10.1037/0033-2909.88.1.144

Taylor, M.P. (1996). "Earnings, Independence or Unemployment: Why Become Self-Employed? Oxford Bulletin of Economics and Statistics. Vol. 58, núm. 2, pp. 253-266.

Torrance, E.P. \& Myers, R.E. (1976). La enseñanza creativa. Madrid: Ed. Santillana.

Van Treuren, K., Randall, B. \& Fry, C. (2012). "Teaching Creativity and Innovation in the Classroom". American Society for Engineering Education. Núm16, T.638, 13746.

Whiting, B.G. (1988). "Creativity and entrepreneurship: How do they relate?". Journal of Creative Behaviour. Vol. 22, núm. 3, pp. 178-193. http://dx.doi.org/10.1002/j.2162-6057.1988.tb00495.x

Winslow, E.K. \& Salomon, G.T. (1987). "Entrepreneurs are more than non-conformists: They are mildly sociopathic". Journal of Creative Behavior. Vol. 21, núm. 3, pp. 202-213. http://dx.doi.org/10.1002/j.2162-6057.1987.tb00477.x

Winslow, E.K. \& Salomon, G.T. (1993). "Entrepreneurs architects of innovation, paradigm pioneers and change". Journal of Creative Behaviour. Vol. 27, núm. 2, pp. 75-88. http://dx.doi.org/10.1002/j.2162-6057.1993.tb01391.x

Young, R. \& Francis, J. (1991). "Entrepreneurship and innovation in small manufacturing firms". Social Science Quarterly. Vol. 72, núm. 1, pp. 149-162.

\section{Notes}

Note 1. Entrepreneurship Identity (Falck, O., et al., 2012) 